DOI 10.18551/rjoas.2019-03.41

\title{
SMALL BUSINESS INDUSTRIES MAPPING IN IMPROVING ECONOMIC GROWTH OF SUB-URBAN AREA
}

\author{
Kussujaniatun Sri ${ }^{\star}$, Warsiki Ayn, Harilaksana Dwi \\ Faculty of Economics, Pembangunan National "Veteran" University, Yogyakarta, Indonesia \\ *E-mail: sri.kussujaniatun@upnyk.ac.id
}

\begin{abstract}
Industry mapping and need assessment are the initial steps in developing industry sector. This research aims at illustrating the industry performance, mapping the potentials of industry development and identifying need assessment of industry in Kepuh Kulon, Bantul, Yogyakarta. The data are obtained from survey method using questionnaires and Focus Group Discussion. The analysis conducted is descriptive statistics analysis. The research results show that there are 30 entrepreneurs of belinjo crackers business and 44 entrepreneurs of the other industries such as bricks, sewing, silver, embroidery, bakery, flour milling, and rice milling. Even though the small businesses have established for years, most of the industries still do not have proper business operation management, from administration and finance aspects to production and marketing aspects. The results of the need assessment show that trainings for administration documentation, financial statement reporting, product innovation, packaging technique, marketing technique, and waste management are needed to improve the capacity of the businesses.
\end{abstract}

\section{KEY WORDS}

Mapping, industry, performance, assessment.

Based on the data from the Central Bureau of Statistics, the economic growth result in Indonesia for the first quarter in 2018 is $5,06 \%$. This number is higher than the economic growth in quarter 1 in 2017 (year on year), which is 5,01\%. Similarly, the small businesses growth rate in 2012-2013 is 24.803 with the increase of 3,94\% (Central Bureau of Statistics, 2018).

In Indonesia, besides playing role in developing the infrastructure and economics, small businesses units also contribute in solving the problem of unemployment. It is easy for small businesses to provide vacancies for job seekers. Therefore, the government pays more attention to the small and medium businesses to maintain the economic condition in Indonesia. Small and medium industries sector has strong endurance to survive against the economic crisis and monetary crisis. Supervision and protection for small and medium businesses are very strategic to produce added sufficient value since the number of the businesses unit is adequate. Therefore, small businesses mapping is necessary to be conducted. Furthermore economic empowerment for the sub-urban society is expected to be done based on the capacity. This is because small industries play important roles in development and economic growth (Warsiki, 2012).

One of the small and simple regions of small industries is in Kepuh Kulon. It is a strategic location to build small industries. Kepuh Kulon is well known as the center of emping industries in Bantul, Yogyakarta. Therefore, Kepuh Kulon has been appointed as the representative of the regions with the productive society both in regional and national scale. It is found out that in Kepuh Kulon, the industries are not just emping industries.

There are other small home industries, such as bricks, rice milling, flour milling, embroidery, sewing, and many others. Thus, Kepuh Kulon is a potential region for small industries. As stated by Kussujaniatun and Kismantoroaji (2017) in their research, it is expected that the society find out and realize that in their region there are many potentials that can be utilized. Therefore, there is a need to study the aspects of social improvement and economic growth in influencing the entrepreneurial behavior. The research shows that 
there is an influence of social improvement and economic growth on the entrepreneurial behavior (Kussujaniatun, 2017).

Industry mapping and need assessment are the proper ways as initial steps to develop industry sector in increasing the economic growth of the society. Business capacity improvement can be conducted by identifying the need assessment of each existing industry so that the appropriate policy can be made for the development of the industries.

The interest of the research is to find out the performance, mapping, and need assessment of the entrepreneurs of the small industries. It is expected that by having the understanding about the mapping of the small industry potential in Kepuh Kulon, the results of need assessment can be implemented to increase the capacity of the businesses.

\section{MATERIALS AND METHODS OF RESEARCH}

Small industries play role in creating job opportunities, expanding employment for urbanization and providing needs flexibility and innovation in economics in general. In crisis moments in Indonesia, both economic crisis and monetary crisis, small industries are able to show their existence to survive and even tend to expand (Fafurida and Dyah Maya Nihayah, 2011).

According to Tri Wahyu Rejekiningsih (2004) small industries include all companies or businesses that turn raw materials into semi-finished materials or turn goods with less value into good with higher values. In addition, Mudrajat Kuncoro (1997) also states that small industry still use traditional technology and simple financial system. This is in line with what has been done by the people in Kepuh Kulon, in which there are still some entrepreneurs of belinjo crackers who still maintain the production process using traditional or manual tools.

Related to small businesses, there are several special criteria as stated by Sutojo, et al (1994) in Baswir (1998):

- More than half of small companies are established as the development of small businesses;

- Besides facing capital problems, other problems faced by small business arise along with the business development level;

- Most of the small businesses are unable to fulfill the administration requirements to obtain loans from banks;

- Almost $60 \%$ of small businesses still use traditional technology;

- Almost half of small companies just use less than $60 \%$ of capacity;

- Market shares of the small businesses tend to decrease due to lack of capital, low technology and low managerial system;

- 7 Almost $70 \%$ of small businesses conduct their marketing directly to the consumers.

One of the regions for small and simple industries that has been realized is in Kepuh Kulon. Kepuh Kulon is one of the strategic regions to build small industries. Kepuh Kulon has been known as one of industry center for emping or belinjo crackers in Bantul regency. According to the research conducted by Kussujaniatun and Kismantoroaji (2017), it is expected that the society identify and realize that in their region there are many potentials that should be developed. Therefore, there is a need ro study about the social development aspect and economic improvement. Another research done by Kussujaniatun (2016), it shows that Bojonegoro regency is one of the cities with the potential to develop creative industries and tourism village. In facing business competition, creativity and innovation are necessary.

Small and medium business industries play important role in economic development and growth. Generally, small business industries open more job vacancies, and contribute more to earn better income. Small business industries tend to take more employees. This can be seen from the fact that around $99 \%$ of the business units in Indonesia are of small and medium business industries. It is noted that they are able to create job vacancies for 99 , 4 million employees. Meanwhile, big industries only take 2, 8 million employees (Ministry of Cooperative and Small and Medium Enterprises, 2010). Therefore, this can help Indonesia to 
improve the welfare of its citizen and to survive in monetary crisis moments. It can be stated that the small business industries have big roles and contributions for the economics in Indonesia in the form of giving opportunity to help people work as employees.

The method used in this research is survey method by using questionnaires via interviews, focus group discussions and observations for the respondents. The type of data in this research is primary and secondary data. The secondary data obtained are related to the small business industries in Kepuh Kulon, while the primary data are obtained directly from the respondents. In line with Sesotyaningsih, Mega \& Manaf (2015) which is conduct the observation and interviews with the local community using literature and institution survey. The respondents in this research are all of the entrepreneurs in Kepuh Kulon, Bantul, Yogyakarta.

The analysis used is descriptive statistics analysis. The description of the performance of each industry will give illustration on how the industries run for all this time. Thus, it can be identified what has been done and what has not been done by the industries. The industry mapping is useful to see the grouping of each type of the industry. Along with Vitasurya (2015) this research emphasizes the involvement of the target as an active subject, making their experience as an integral of research, finding problems, and solving problems by targeting the empowerment context of the research subject.

Meanwhile, need assessment is used to identify things needed by the industries to improve their business capacity. There are three aspects evaluated in need assessment stage. The three aspects include administration, production, and marketing. The framework of this research is described in Figure 1, and it is expected that it can explain the performance of the small business industries. The small business industry mapping and need assessment are the initial steps in identifying what things needed to improve the business capacity.

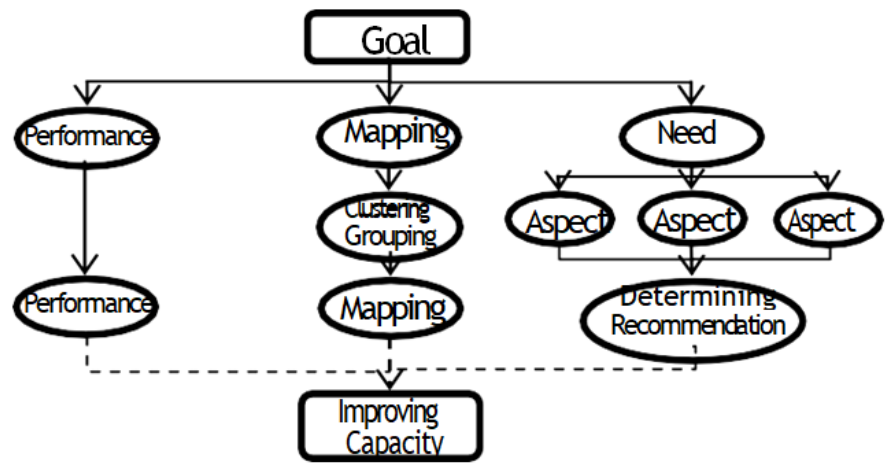

Figure 1 - Research Framework

\section{RESULTS AND DISCUSSION}

Research results show that there are 8 types of small industries. There are 74 entrepreneurs of the small business industries in Kepuh Kulon, Bantul that become the respondents of this research. Most of them are the entrepreneurs of emping industry as many as 30 persons. Most of them are women (71\%) and $75 \%$ of them are in the range of 40-65 years old with the education level of elementary school $(60 \%)$ and junior high school $(25 \%)$.

From the 74 entrepreneurs of the small business industries, there are some of them who have established the industries for 25-40 years, and most of them deal with emping/ belinjo crackers industries as many as 30 entrepreneurs. It shows that the business climate in Kepuh Kulon is remarkable. The industries that have been running for years are expected to give positive effects to the development of the region.

Even though some industries have run for years, most of them are still not well managed. This can be seen from the administration documentation. Most of the industries still do not have administration documentation of their businesses. This condition shows that they still do not understand the importance of administration documentation for a business. 
Similarly, those industries still do not apply financial reports for their business. The poor documentation both for administration and for financial report may occur due to the low education level of the owners of the industries. From the research result, $60 \%$ owners are the graduates of elementary school, $5 \%$ did not even graduate from elementary school, $25 \%$ are the graduates of junior high school, and $10 \%$ are the graduates of senior high school. These facts cause the lack of knowledge about documentation of a business.

Most of the business capitals in the industries are taken from private capital. Only a few owners get more business capital by having loans from the banks to expand the businesses. This is caused by several reasons. First, they are afraid of being unable to pay the credits since they worry they cannot pay the installment each month. Their low level of education makes them never think of expanding their business to be more advanced. The second reason why the entrepreneurs do not want to borrow some loans from the banks is that because of the difficulty to get loans from the banks or other financial institutions. This is because they cannot fulfill the administrative and technical requirements asked by the banks. The most difficult requirement that they need to fulfill is about collaterals. Not all of the owners have sufficient property or assets to serve as collaterals to secure the loans. Most of the industries are home business industries, and therefore it is normal if they do not have sufficient assets or property.

The monthly profit for each business industry in Kepuh Kulon ranges from five to fifteen million rupiah. There are also some industries with more than fifteen million rupiahs, but they are only less than $6 \%$ of the total industries in Kepuh Kulon.

Business assets owned by most entrepreneurs in Kepuh Kulon are very small. This occurs since most of the industries are home-based industries with small profit.

Seen from the types of the production tools that they use, most of the small business industries still use simple tools. This is because of the limited knowledge of the owners about the effective and efficient technology that can be applied nowadays. Therefore, there is a need to supervise and to direct them about the use of effective and efficient technology so that the productivity of the industries in Kepuh Kulon can increase.

The number of the employees in each industry is also minor, which is less than 5 employees. That number includes the owner and relatives who help to run the business. This is because the home industries are family industries that are conducted from generation to generation. From the research result, it can be seen that the limited quality of the human resources both from formal education and from knowledge and skills really influence the business management. Thus, it is difficult for the businesses to improve and grow optimally since the people are hard to adopt the advance of the new technology to increase their product competitiveness.

Most of the small business industries in Kepuh Kulon are emping business. The 30 emping entrepreneurs also still employ simple packaging technique. The simple product packaging technique is still done manually. As a result, the appearance of the packages is still not in its optimum look. Marketing is a crucial aspect that becomes the significant factor of the success of a business. Networking is the main key of the marketing success (Simmons Geoff, 2008). The product marketing technique of the industries is still simple and does not use advance technique, which is merely by word of mouth. Most of them still cannot sell their own products, but they sell it with the help of collectors. There are only four business industries that are able to sell their own products to the consumers. Right now, there has not been innovation both in the packaging process and in marketing system. The product quality itself still cannot fulfill the market demand. For example, most of the emping business industries do not create innovation on the taste variations and shape variations of the emping/belinjo crackers. There are only two entrepreneurs of emping industries who start to produce emping with three taste variations of salty, sweet, and spicy with two shapes of triangle and square.

After identifying the performance of the industries in several aspects, there is a need to conduct guidance, training, and knowledge transfer as well as business supervision for the entrepreneurs of the industries. It can also be stated that the performance of most small business industries in Kepuh Kulon is still low. 
The minimum knowledge about business development strategy shows that there are many things that should be done to maintain the industries. The performance of the industries must be improved by conducting business management training, efficient and effective technology application, and business supervision especially in conducting differentiation for emping or belinjo crackers in terms of creativity and innovation of the taste and shape of the emping. This indicates that the trainings for the entrepreneurs is important so that the business industries can compete in increasing the price of the creative products and in making innovation in product designs (Kussujaniatun, 2009a). With those efforts, it is expected that the industry performance can increase and eventually will improve the welfare of the people.

The small businesses industries are mapped based on the type of the industries. Each industry in Kepuh Kulon has different condition and distribution. Most of the industries are emping industries, and they form a cluster in Kepuh Kulon. There are also industries of cassava crackers/emping and cassava and tubers flour milling with the neighboring locations. Besides, there are industries of bricks, silver, and embroidery with a bit distant locations from the emping industries. Meanwhile, rice milling industries are spread out in the center of Kepuh Kulon. Things to do in improving the business capacity are the trainings for making administration documentation, reporting financial statement, product tools innovation, packaging technique, marketing technique, getting business capital, getting easy access for raw material, and managing waste.

The following is the discussion of each industry profile based on the industry type in Kepuh Kulon.

Most of the industries in Kepuh Kulon are emping industries. There are 30 emping industries in this village, and it is expected that the products can have higher market value.

There are no documentations for administration and finance. For all this time, the entrepreneurs never record the production cost that they spend, income they get, and their productivity in producing the emping. This is due to the poor knowledge about bookkeeping.

In terms of production, the raw materials used in production process are taken from around Kepuh Kulon. However, most of them admit that they have trouble in obtaining raw materials, both from the availability and from the fluctuate price.

The tools that they use for production process are just simple tools. In producing the crackers/emping, they just utilize simple manual tools so that the production is less optimal. The average employees for the production process are less than five persons, and all of them are from Kepuh Kulon.

Most of the problems that they face deal with capital and technology in the production process especially technology in sautéing process of the crackers. In addition, they also have problems in their simple management system that lead to unidentified loss and profit. Besides, they also have no skills in using the technology as media to market their products.

Traditionally, the emping industries are given from generation to generation. Until now, most all of the people still preserve the tradition to maintain the emping industries. How ewer, it is inevitable that inheriting this industries for the next generation is not easy. For product packages, they still use simple packaging. They do not know yet about labelling the products and making interesting packages. In marketing aspect, they also use simple marketing. They have never done promotions to sell their products. Their products are sold only by word of mouth.

In Kepuh Kulon, there are two businesses of rice milling. The large farming area in this region leads to the rice production. Therefore, the rice milling industries are established.

Seen from the distribution, the locations of the rice milling industries spread out in the center of Kepuh Kulon. The two rice milling industries enable the local farmers to process their production results.

Seen from the administration aspect, of the five rice milling industries, there are only two that conduct the documentation both for the administration and for the finance. However, the documentation or the bookkeeping itself still cannot fulfill the good standard of bookkeeping. This occurs due to the poor knowledge about the importance of proper bookkeeping. 
Seen from production aspect, the business profit of these industries are relatively big. The average profit of the two rice milling industries may reach five up to fifteen million rupiahs per month. This shows that the businesses are potential and need to be maintained. The tools used in these businesses are considered to be modern since they have used rice milling machines. The employees are around six persons and all of them are from Kepuh Kulon. There is no difficulty in terms of marketing, since they do not need to do promotions. The rice farmers will directly come to the rice milling industries to process their harvest results. Therefore, the farmers do not need to work hard on the marketing.

There are 15 industries of bricks in Kepuh Kulon. The existence of clay in this region enables the establishment of these industries. Based on the research result, it is found out that most of the bricks industries still do not have documentation or bookkeeping both for the administration and for the finance. The average profit is around one up to five million rupiahs per month.

The tools used for the production process are simple. For the drying process, they still depend on the sun shine. Therefore, in the raining season, the production results of the bricks tend to decrease. For the marketing technique, they just depend on the consumers who come to buy the bricks. It is unfortunate that these industries still have many limitations. Therefore, there is a need for the practitioners or academician to help maintaining their existence.

There are 8 industries producing silver accessories in Kepuh Kulon. Kepuh Kulon is well known for its emban akik (akik ring) made of silver. The products are neat and have great quality with cheaper price compared to the products in other regions. The production cost is around fifty up to ninety five thousand rupiahs, depending on the complexity of the design and the materials used. The production process of the akik takes 1-2 weeks. Besides producing emban akik, the industries also produce wedding rings.

The profit ranges from five to fifteen million rupiahs per month. The tools used in the production process are still simple. It is necessary for the expert of product design to give training for the employees so that the designs of the silver accessories can be more varied. The marketing technique that they use is still simple as well.

There are four industries of embroidery in Kepuh Kulon. Most of the products of the embroidery industries are clothes and prayer dresses with certain threads and motives.

The price is determined by considering the size, motives, types of threads, and soldering. The tools are still minimum, such as rulers, scissors, soldering tools, and simple embroidery machine.

The profit ranges from five to ten million rupiah per month. The employees for the production process are less than five persons and all of them are from Kepuh

Kulon. They haven't done any documentation both for administration and for finance. Until now the marketing technique is still simple, only by word of mouth.

There are four locations of bakery industries in Kepuh Kulon. The types of the kue that they produce are kue basah/wet cake (moist and soft cakes) and kue kering/dried kue (cookies). Wet kue include lemper, appam, kue rissoles, kue mangkok (cake bowl), kue beras/rice kue, and kue cucur. Dried kue include kue kuping gajah, untir-untir, kue kacang telur (egg and peanut), kue nastar, astar, and ampyang. The profit of the bakery is around two hundred thousand rupiahs per day or five until ten million rupiahs per month.

The employees for the production process are less than five persons and all of them are from Kepuh Kulon. Until now, they haven't done any documentation both for administration and for finance. The product packaging technique is still simple. Similarly, the marketing technique is still simple, only by word of mouth without any promotions to sell the product.

There is one industry producing tubers and cassava flour in Kepuh Kulon. The tubers and cassava flour include taro flour, sweet potato flour, cassava flour, carrot flour, pumpkin flour, arrowroot flour, suweg flour, jicama flour, banana stem flour, and others. They produce flour from any possible and available raw materials. The tools used in the production process are also simple. In production process, the raw materials used are taken in Kepuh Kulon and 
outside Kepuh Kulon. In the process, they just use simple manual tools, and therefore the results are not optimized.

The profit ranges from five to ten million rupiahs per month. For product packaging, they simply package the products in simple way. They don't know yet about labeling and proper packaging technique. The marketing technique is still simple, only by word of mouth.

There are 10 sewing business industries in Kepuh Kulon. The productions really pay attention to the neat sewing and the clothing designs. Those become the leading advantage of the sewing industries in Kepuh Kulon. The entrepreneurs really maintain the quality of their products. However, the sewing machines that they use are still simple. The employees for the production process are less than five persons and all of them are from Kepuh Kulon. The profit ranges from five to ten million rupiahs per month. Until now, they haven't done any documentation both for administration and for finance.

The result of Focus Group Discussion with the owners of the businesses and the data analysis in Kepuh Kulon show that there is some information about things needed by each industry group in Kepuh Kulon to improve their business capacity.

After identifying the need assessment of each industry, follow up is needed in the form of further research about the empowerment of the society. The expectation is that if the need assessment is fulfilled, then the business capacity will be improved and eventually will increase the contribution of small business sector in Kepuh Kulon.

\section{CONCLUSION}

There are some potential for the development of 8 small business industries in Kepuh Kulon, including: belinjo crackers/emping, bricks, sewing, silver, embroidery, bakery, rice milling, and tubers and cassava flour milling. Most of the people in the community conduct the business of belinjo cracker production. There are 74 entrepreneurs of the small business industries and most of them (30 people) are the entrepreneurs of emping industry. It shows that the businesses done in Kepuh Kulon run well. It is expected that the eight small business industries, especially emping business, which has established for long, can give positive effect to improve the business capacity.

Based on their performance, most of the business industries still run without proper business management. This can be seen from several aspects that show that most of the industries in Kepuh Kulon aren't able to manage their business well and still do not have proper administration and financial documentation. The low education level of the owners of the industries is the cause of the poor financial and administration documentation. Based on the research result, $60 \%$ of the business owners in Kepuh Kulon are the graduates of elementary school. Most of the business owners in Kepuh Kulon use their own capital as the business capital. There are only a few of them who make loans to the bank to get business capital to expand their business. The average profit of the emping businesses is around five until fifteen million rupiahs per month, while the other eight business obtain five until ten million rupiahs per month as their profit. Most of the business industries still use simple production tools and simple product packaging technique. Similarly, they still also apply simple product marketing technique. Each industry in Kepuh Kulon has different condition and location distribution.

Most of the industries are emping business industries. Those industries form cluster pattern so that they are in the neighboring locations. In addition, there are also industries of bricks, silver, and embroidery with distant location from emping industries. Besides, there are also industries of bakery, flour milling, and rice milling spread out in the center of Kepuh Kulon.

Based on the performance of the industries in those aspects, it can be stated that the performance of most industries in Kepuh Kulon is still low. Many things must be done to maintain the business industries due to the minimum knowledge about business development strategy. The performance of the industries must be improved by conducting business guidance, trainings, effective technology application, and business supervision. 
The needs to improve the business capacity include trainings for administration documentation, financial statement reporting, production tools innovation, packaging technique, marketing technique, business capital, easy access of raw material, product innovation, and product waste management. With those training, it is expected that the industries' performance will improve and eventually will improve the welfare of the society. Based on the result of need assessment in each industry, there is a need to follow up the results both in the form of conducting research and in the form of giving service to the society. It is expected that if the need assessment is fulfilled, it can improve the business capacity in each industry, and eventually will increase the income of the society, and surely it will improve the contribution to the industry sector acceptance in Kepuh Kulon.

\section{REFERENCES}

1. Arsyad, Lincolin. (2010). Ekonomi Pembangunan. Edisi 5. Yogyakarta: UPP STIM YKPN.

2. Badan Pusat Statistik. (2010). Gunungpati Dalam Angka. Jawa Tengah.

3. Depkeu.go.id. "UMKM berpotensi meningkatkan pendapatan negara".21 Juli 2018. http://bppk.kemenkeu.go.id/id/berita-pajak/12515-umkm-berpotensi-meningkatkanpendapatan-negara.

4. Fafurida, F., \& Nihayah, D. M. (2012). Pengembangan Unit Usaha Industri Kecil Melalui Metode Pemetaan and "Need Assessment". Jejak: Jurnal Ekonomi and Kebijakan, 5(1).

5. Geoff Simmons, Gillian A.Armstrong \& Mark G. Durkin. (2008). A conceptualization of the determinants of small business website adoption setting the research agenda. International Small Business Journal, 26; 351.

6. Jhingan. M.L. (1994). Ekonomi Pembangunan and Perencanaan. Jakarta: Rajawali Pers.

7. Kelompok Kerja Indonesia Design Power. (2008). Rencana Pengembangan Ekonomi Kreatif Indonesia 2009-2015. Departemen Perdagang- an RI.

8. Kompas.com. 7 Mei 2018. BPS: Kuartal I 2018, Pertumbuhan Ekonomi Indonesia 5,06 Persen. 21 Juli 2018. https://ekonomi.kompas.com/read/2018/05/07/113 925626/bpskuartal-i-2018-pertumbuhan-ekonomi-indonesia-506-persen

9. Kuncoro, Mudrajad. (2010). Ekonomika Pemba-ngunan: Masalah, Kebijakan, and Politik (Edisi.5). Jakarta: Penerbit Erlangga.

10. Kussujaniatun, S. 2016. Tourism Potential Mapping Using Ethnographic Approach: A Case Study of Local Tourism Industry. International Conference Social Science And Technology Engineering, JEAS n0 5372, Medwelljournals, 2017.

11. Kussujaniatun,Sri.,Kismantoroadji, Pengaruh Peningkatan Sosial and Ekonomi terhadap Perilaku.

12. Kewirausahaan, International Conference on Technology Enginneering and Social Science, HASE, Nabu Research Academy, 2017

13. Kerajinan Daerah: Studi Kasus Kerajinan Gerabah di Kecamatan Plered, Kabupaten Purwakarta. ITB J.Vis. Art \& Des, Vol. 6 No. 1, 2012:28-41.

14. Laksana, Dwi Har.2013.Penelitian mandiri judul Kepercayaan Merek Memediasi Pengaruh Keterlibatan Mahasiswa terhadap keputusan Memilih Perguruan Tinggi di Yogyakarta.

15. Mudrajad Kuncoro, 1997, Ekonomi Pembangunan (Teori, Masalah and Kebijakan ), Akademi Manajemen YKPN, Yogyakarta

16. Saputro, J.W., Putu Wuri Handayani, Achmad Nizar Hidayanto, \& Indra Budi. (2010). Peta Rencana (Roadmap) Riset Enterprise Resource Planning (ERP) dengan Fokus Riset Pada Usaha Kecil and Menengah (UKM) di Indonesia. Journal of Information Systems Vol. 6, No. 2:140-145.

17. Sesotyaningtyas, Mega \&Manaf, Asnawi.(2015). Analysis of Suistainable Tourism Village Development at Kutoharjo Village, Kendal Regency of Central Java. Procedia - Social and Behavioral Sciences, 184, 273-280.

18. Simanjuntak, Oliiver S. 2014. Studi Awal Industri Pariwisata di Kecamatan Entikong. 
19. Susilo, S.Y., Krisnadewara, P.D., \& Soeroso, A. (2008). Masalah and Kinerja Industri kecil Pascagempa: Kasus di Kabupaten Klaten (Jateng) and Kabupaten Bantul (DIY). Jurnal Akuntansi Bisnis and Manajemen, Vol. 15 No. 2 Agustus 2008, hal. $271-280$.

20. Tarigan, Y.P., \& Sri Susilo, Y. (2008). Masalah and Kinerja Industri Kecil Pascagempa: Kasus Pada Industri Kerajinan Perak Kotagede Yogyakarta. Jurnal Riset Ekonomi and Manajemen, Vol. 8 No. 2 Mei 2008, hal. $188-199$.

21. Triharini, Meirina, Dwinita Larasati, \& R. Susanto. (2012). Pendekatan One Village One Product (OVOP) untuk Mengembangkan Potensi.

22. Tri wahyu rejekiningsih (2004). Dinamika Pembangunan Universitas Diponegoro Semarang. Vol. 1 No. 2 Desember 2004, hal. 125-136.

23. Vitasurya, Vicentia Reni. (2015). Local Wisdom for Sustainable Development of Rural Tourism, Case on Kalibiru and Lopati Village, Province of Daerah Istimewa Yogyakarta. Procedia - Social and Behavioral Sciences, 216, 97-108.

24. Warsiki,AYN. 2012. Model Pengembangan Pemberdayaan Dalam Peningkatan Kualitas Hidup Pada Masyarakat Miskin Kota Yogyakarta. 